\title{
In situ measurements of benthic primary production, respiration and nutrient fluxes in a hypersaline coastal lagoon of SE Brazil
}

\author{
Bastiaan Knoppers ${ }^{1}$, Weber Friederichs Landim de Souza ${ }^{1}$, Marcelo Friederichs Landim de Souza ${ }^{1}$ Eliane \\ Gonzalez Rodriguez $z^{2}$ Elisa de Fátima da Cunha Viana Landim ${ }^{1}$ \& Antonio Romanazzi Vieira ${ }^{1}$ \\ ${ }^{1}$ Universidade Federal Fluminense, Departamento de Geoquímica \\ (Morro do Valonguinho, s/n , 24020-007, Niterói, RJ, Brasil) \\ ${ }^{2}$ Instituto de Estudos do Mar Almirante Paulo Moreira \\ (Caixa Postal 28390, Arraial do Cabo, RJ, Brasil)
}

- Abstract: Benthic oxygen and nutrient fluxes were measured in a section of the hypersaline carbonate-rich coastal lagoon of Araruama, SE-Brazil. In situ incubations of the sediment surface $\left(Z_{m}=1,5\right)$ were performed at one station with light/dark chambers during september 1993 (early spring period) and april 1995 (early autumn period). The carbonate-rich sediments were covered by 1-3 mm thick microalgal mats, dominated by the cyanobacteria Phormidium sp, Oscillatoria $\mathrm{sp}$, and Lyngbya sp. Benthic net primary production rates were $15.4 \pm 0.7 \mathrm{mmolC} / \mathrm{m}^{2} / \mathrm{d}$ in early spring and $33.8 \pm 8.8 \mathrm{mmolC} / \mathrm{m}^{2} / \mathrm{d}$ in early autumn, total community respiration rates attained $35.3 \pm 7.2$ and $65.7 \pm 16.9 \mathrm{mmolC} / \mathrm{m}^{2} / \mathrm{d}$, and pelagic primary production rates $1.7 \pm 0.7$ and $4.0 \pm 1.4 \mathrm{mmolC} / \mathrm{m}^{2} / \mathrm{d}$, respectively. Total community metabolism was thus heterotrophic and mainly driven by benthic metabolism. The benthic release rates of ammonia were $0.65 \pm 0.32 \mathrm{mmol} / \mathrm{m}^{2} /$ day in early spring and $0.58 \pm 0.42 \mathrm{mmol} / \mathrm{m}^{2} /$ day in early autumn, but were near to negligible for orthophosphate. Pelagic primary production was limited by phosphorous, in part, by the preferential release of ammonia over orthophosphate from the sediment-water interface. The benthic primary production and nutrient release rates were within the range of other eury-to hypersaline carbonate-rich environments characterized by non- consolidated algal mats.

- Resumo: Fluxos bênticos de oxigênio e nutrientes foram medidos numa seção da lagoa hipersalina e carbonática de Araruama, SE-Brasil. Incubaçōes in situ da superfície do sedimento $\left(\mathrm{z}_{m}=1,5\right)$ foram realizadas em uma estação com câmaras claras/escuras nos meses de setembro de 1993 (início da primavera) e abril de 1995 (início do outono). Os sedimentos ricos em carbonatos eram recobertos por um tapete microalgal de 1-3 mm, dominados pelas cianobactérias Phormidium sp, Oscillatoria sp e Lyngbya sp. As taxas de produção primária líquida foram 15,4 $\pm 0,7$ $\mathrm{mmolC} / \mathrm{m}^{2} / \mathrm{d}$ no início da primavera e $33,8 \pm 8,8 \mathrm{mmolC} / \mathrm{m}^{2} / \mathrm{d} \mathrm{no} \mathrm{início} \mathrm{do} \mathrm{outono,}$ as taxas dẹ respiração total da comunidade alcançaram $35,3 \pm 7,2$ e $65,7 \pm 16,9$ $\mathrm{mmolC} / \mathrm{m}^{2} / \mathrm{d}$, e as taxas de produção primária pelágica $1,7 \pm 0,7$ e $4,0 \pm 1,4$ $\mathrm{mmolC} / \mathrm{m}^{2} / \mathrm{d}$, respectivamente. Desta forma, o metabolismo total da comunidade mostrou-se heterotrófico e guiado principalmente pela contribuição bêntica. As taxas de liberaçāo bêntica de amônia foram $0,65 \pm 0,32 \mathrm{mmol} / \mathrm{m}^{2} /$ dia no início da primavera e $0,58 \pm 0,42 \mathrm{mmol} / \mathrm{m}^{2} /$ dia no início do outono e insignificantes para fósforo. $O$ fósforo representou o elemento limitante da produçao primária pelágica, em parte, pela liberação preferencial de amônia sobre ortofosfato a partir da interface água-sedimento. A produção primária bêntica e as taxas de liberação de nutrientes se enquadraram dentro da faixa estabelecida para outros sistemas eurye hipersalinos carbonáticos, caracterizados por tapetes algais não-consolidados.

- Descriptor: Primary production, Respiration, Nutrients, Benthic Interface, Hypersaline lagoon, Brazil.

- Descritores: Produção primária, Respiração, Nutrientes, Interface bêntica, Laguna hipersalina, Brasil. 


\section{Introduction}

Total community metabolism and primary production rates of marine hypersaline carbonate-rich environments may equal or even surpass those of other hyposaline organic-rich estuarine systems (Bauld, 1981; Nixon,1982; Smith, 1988; Javor \& Castenholz, 1984; Knoppers, 1994). In most hypersaline systems, primary production is largely driven by benthic phototrophic communities, which thrive at the sediment-water interface either as patchy algal films or consolidated, up to many centimeters thick, algalbacterial mats. The most complex consist of a photosynthetically active zone at the top, with diatoms, cyanobacteria, and anoxygenic phototrophic bacteria, and a light limited anoxic zone below, where part of the produced organic matter is degraded mainly by respiratory sulphate reduction. Primary production is maintained by nutrients from the overlying water and also by the feedback from within the mats or underlying surface sediments. The algal mats thus serve as efficient nutrient traps and promote the accretion of organic matter and bio-minerals in surface sediments (Bauld, 1981 and 1984; Jörgensen et al.,1983; Krumbein,1983; Cohen et al.,1984; Javor and Castenholz, op. cit.; Javor, 1989; Joye et al.,1996).

In most of these environments, pelagic and benthic primary production is limited by phosphorous, due to the additional control of phosphorous dynamics by calcium carbonate reactions, particularly, at the sediment-water interface (Atkinson and Smith, 1983; Atkinson,1987; Smith, op. cit.; Ullman and Sandström, 1987). In contrast, nitrogen is usually abundant. Under certain conditions, it may however limit primary production, but is often compensated by cyanobacterial nitrogen fixation (Javor, op. cit.). Most of the studies on algal mats, have focused on community metabolism and the mechanisms which control the anoxygenic degradation of organic matter and the formation of bio-minerals. However, there is still great paucity of information on benthic nutrient fluxes controlled by algal mats and the sediment-water interface of hypersaline carbonate-rich systems.

This study reports on short events of benthic primary production, respiration, and nutrient fluxes of a hypersaline carbonate-rich lagoon embayment of the State of Rio de Janeiro, Brazil. Benthic oxygen and nutrient fluxes were measured by In Situ incubations of the sediment surface with simple manually operated chambers (Pamatmat,1971; Zeitzschel and Davies,1978).

\section{Material and methods}

\section{Study area}

The elliptical-shaped lagoon embayment of São Pedro D'Aldeia (SPA) is one of the seven open cells of the $220 \mathrm{~km}^{2}$ choked coastal lagoon system of Araruama ( $23^{\circ} 08^{\prime} \mathrm{S}$ and $42^{\circ} 08^{\prime} \mathrm{W}$ ), (Fig. 1). The embayment is delimited from Araruama's $14 \mathrm{~km}$ long tidal channel by a headland elongated with a cuspidal spit, but has direct water exchange with the central part of the lagoon system (Kjerfve et al., 1996). The embayment has a surface area of $15 \mathrm{~km}^{2}$, a mean depth of $3.3 \mathrm{~m}$, and the mean annual salinity is 52\%o. The climate is semi-arid, with a mean annual rainfall of $800 \mathrm{~mm}$, and the lagoon exhibits a surplus evaporation to precipitation balance at a ratio of 1.3:1 (Barbieri, 1975; Kjerfve et al., op. cit.).

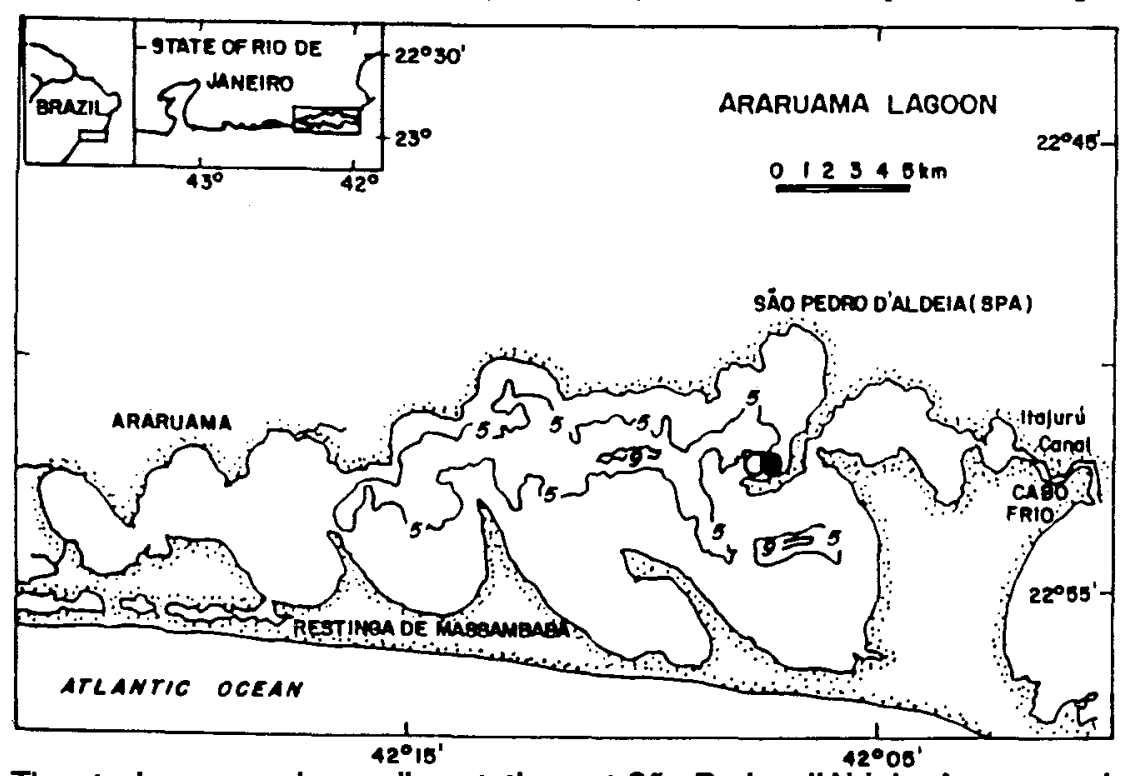

Fig. 1 - The study area and sampling stations at São Pedro d'Aldeia, Araruama Lagoon. - represents the site of benthic flux measurements and $O$ of pelagic primary production measurements. 
The sandy sediments between 0 and approximately $3 \mathrm{~m}$ water depths (Muehe, 1994) are rich in carbonates and relatively poor in organic carbon ( $<3 \%$ of the fraction $<2$ mm; Campos et al., 1979). Abundant deposits of $2-4 \mathrm{~cm}$ lengthy shells of the bivalve Anomalocardia brasiliensis are found within the surface sediments. The shells serve as a favourable substrate for biofilms and patchy distributed microphytobenthos populations with a mat thickness of 1 to 3 millimeters. These consist mainly of cyanobacteria (e.g. Phormidium sp, Oscillatoria sp and Lyngbya sp), which also represent the dominant autotrophs of the Araruama lagoon system (Baeta Neves, 1983; Baeta Neves, pers. comm). The embayment is oligotrophic in winter and slightly mesotrophic in summer (Landim de Souza,1993), receives some effluent discharge from the township of São Pedro D'Aldeia, and surface sediments are sporadically dredged for the commercial production of sodium-carbonate (Barbieri, 1975).

\section{Sampling and Instrumentation}

The field work was conducted in early spring $(06.10-10.10,1993)$ and early autumn $(06.04-11.04,1995)$ at one station $\left(\mathrm{z}_{\mathrm{m}}=1.5\right.$, Fig. 1) within the sand/silt carbonate-rich girdle of the embayment. In Situ measurements of benthic oxygen and nutrient fluxes were conducted by the employment of dark and transparent acrylic domes ("bell-jars"; $\mathrm{V}=55 \mathrm{dm}^{3}, \mathrm{~A}=0.28 \mathrm{~m}^{2}$; Fig. 2), under conditions of continuous gentle stirring and incubation periods varying between 6 to $8 \mathrm{hrs}$ during the day. The stirring mechanism was adjusted by rhodamine mixing experiments to yield a homogenization of the incubated water within 5 minutes (Klump \& Martens, 1987). The bell-jars were gently placed on the sediments and direct observations assured that the bell-jars' rim was embedded at least $4 \mathrm{~cm}$ within the sediment surface, enclosing the overlying water. An hour thereafter, bell-jar samples were taken via a lateral port with $50 \mathrm{ml}$ plastic syringes and those for dissolved oxygen determinations immediately fixed on the sampling skiff and analysed at the shore laboratories. A total of 14 incubations (7 dark and 7 light) were performed.

The benthic fluxes (F) were calculated according to Hargrave (1978), as follows:

$$
F=\left\{V \cdot\left(C_{o}-C_{t}\right) / A\right\} \cdot\left(10^{4} / T\right)
$$

where,

$\mathrm{F}$ is the element flux in grams or $\mathrm{mmol} / \mathrm{m}^{2} / \mathrm{day}, \mathrm{C}_{0}$ the element concentration at the beginning and $\mathrm{C}_{t}$ at the end of the incubation period, A the surface area of the sediment,
$\mathrm{V}$ the volume of the chamber, and $\mathrm{T}$ the time of incubation in hours. The factor $10^{4}$ converts the incubated area from $\mathrm{cm}^{2}$ to $\mathrm{m}^{2}$.

The daily net and gross primary production rates correspond to estimates covering a light period of $\mathbf{8 . 8}$ hours. This represents the time period during which more than $95 \%$ of the daily photosynthetically active radiation was available to the primary producers in the study periods. This was established by the diurnal light curves of this study and earlier on for $L$. Guarapina, a coastal lagoon of the same region (Moreira \& Knoppers, 1990). The estimates of total community respiration and nutrient fluxes estimated during the day, were extrapolated according to common practice to a period of $24 \mathrm{hrs}$ (Hargrave, 1978; Zeitzschel \& Davies, 1978; Florek \& Rowe, 1983; Machado \& Knoppers, 1988).

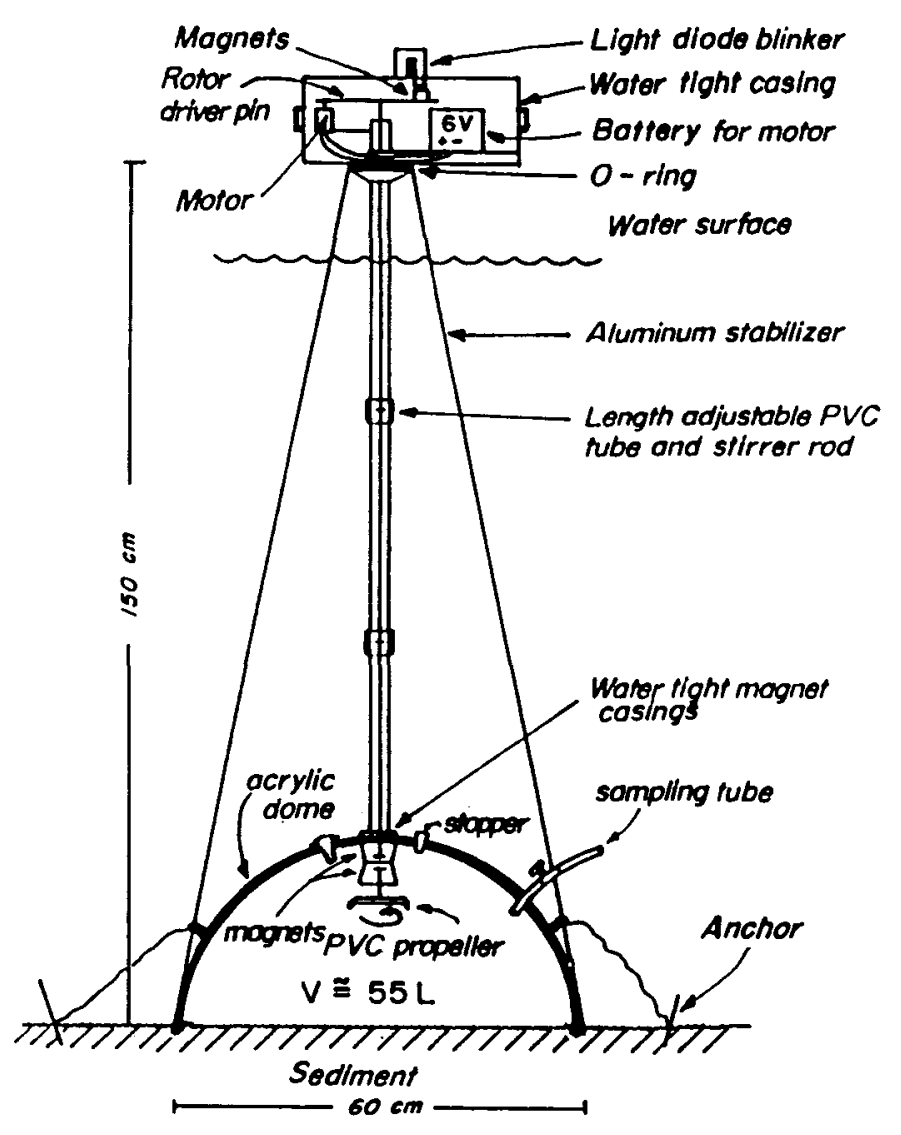

Fig. 2. The simple manually operated benthic chamber (bell- jar) of this study.

Conversions of dissolved oxygen to carbon assimilation or respiration were performed by applying photosynthetic and respiratory quotients (PQ and $R Q$, respectively) of 1 . This is in contrast to the generally accepted $P Q$ values of 
1.2 or 1.3 for phytoplankton (Williams \& Robertson, 1991) and the RQ value of 0.77 for decomposing organic matter (Hargrave, 1969). The values at unity were adopted due to: 1) the lack of concomitant rate measurements of carbon dioxide and dissolved oxygen, which are necessary to establish substantial $P Q$ and $R Q$ values, and 2) to eliminate a further bias when comparing pelagic (phytoplankton) with benthic (microphytobenthos) primary production. For example, PQ values of benthic algal mats may, in accordance to population composition and environmental conditions, be subject to extreme variability (Javor \& Castenholz, 1984; Epping \& Jörgensen, in press).

Because of the low pelagic primary production in Araruama lagoon (André et al., 1981), the in situ light/dark bottle ${ }^{14} \mathrm{C}$-technique was adopted (Steemann-Nielsen, 1954; Strickland \& Parsons, 1972). Samples were taken at surface, mid-, and bottom-depths of a $2 \mathrm{~m}$ water column, adjacent to the site of the benthic incubations (Fig. 1). Each sample was innoculated with $1 \mathrm{ml}$ of $10 \mu \mathrm{Ci}$ sodium bicarbonate (Carbon-14 Agency, Denmark) and incubated for $6 \mathrm{hrs}$. Thereafter, the particulate matter was retained on $0.45 \mathrm{~mm}$ Millipore filters, fumed in a desiccator with $\mathrm{HCl}$ acid for approximately $12 \mathrm{hrs}$, and the filters inserted in scintillation vials with Emulsifier-Safe liquid from Packard. Radioctivity counts were performed with a Packard scintillation counter Model B1600TR at the Institute of Marine Studies Almirante Paulo Moreira (IEAPM, Brazilian Navy). Irradiance curves for calculations of the daily rate of primary production were obtained from a Li-Cor integrator model 550B and a sensor model $190 \mathrm{SB}$.

Temperature and salinity were measured with a thermometer and a hand refractometer (Shibuya Model-S1). Dissolved oxygen was determined according to the Winkler method (Grasshoff et al., 1983) with an automatic Metrohm Dosimat titration unit with a resolution of $0.01 \mathrm{ml}$. The nutrients ammonia, nitrite, nitrate, and orthophosphate were analyzed according to Grasshoff et al. (op. cit.). Water samples were filtered across Whatmann GF/F filters, frozen at the shore laboratory, and henceforth transported on ice in the dark to the main laboratory. Seston Dry Weight (TSS) and Chlorophyll $a$ (Chl. a) were determined as in Lenz (1971) and Strickland \& Parsons (1972), respectively.

\section{Results}

\section{The water column}

Table 1 depiets the mean water column values of temperature (T) and salinity (S) and the mean integrated water column $\left(Z_{m}=2\right)$ concentrations of some standard chemical properties for the two sampling campaigns. Temperatures and salinities were 24 to $27^{\circ} \mathrm{C}$ and 52 and $54 \%$ in early spring and early autumn, respectively, and the water column was homogeneously mixed throughout both study periods. Prior to the incubations in the early morning, the dissolved oxygen saturation levels of the bottom waters were always above $70 \%$. Dissolved inorganic nitrogen (DIN) attained about $12 \mathrm{mmol} / \mathrm{m}^{2}$ in early spring and $<5 \mathrm{mmol} / \mathrm{m}^{2}$ in early autumn. Ammonia $\left(\mathrm{NH}_{4}-\mathrm{N}\right)$ and nitrate $\left(\mathrm{NO}_{3}-\mathrm{N}\right)$ were present at more or less equal proportions. Dissolved inorganic phosphate (DIP) concentrations were low between 0.07 and $0.14 \mathrm{mmol} / \mathrm{m}^{2}$. Consequently, DIN:DIP ratios were high, with a mean of 178:1 in early spring and $34: 1$ in early autumn. Concentrations of suspended matter (TSS) were fairly low

Table 1. Integrated water column concentrations $(Z=2 m, n=3)$ during the two study periods in the lagoon embayment of São Pedro D'Aldeia/Araruama.

\begin{tabular}{ccccc}
\hline Parameter & Abrev. & Unit & Early Spring & Early Autumn \\
\hline Temperature & $\mathrm{T}$ & ${ }^{\circ} \mathrm{C}$ & 24 & 27 \\
Salinity & $\mathrm{S}$ & $\%$ oo & 55 & 54 \\
Dissolved Inorganic Nitrogen & $\mathrm{DIN}$ & $\mathrm{mmol} . \mathrm{m}^{-2}$ & 11.9 & 4.7 \\
Ammonia & $\mathrm{NH}_{4}{ }^{+} \mathrm{N}$ & $\mathrm{mmol} . \mathrm{m}^{-2}$ & 5.1 & 3.6 \\
Dissolved Inorganic Phosphate & $\mathrm{DIP}$ & $\mathrm{mmol} . \mathrm{m}^{-2}$ & 0.07 & 0.14 \\
DIN : DIP ratio & $\mathrm{N}: \mathrm{P}_{\mathrm{at}}$ & & 178 & 34 \\
Seston Dry Weight & $\mathrm{TSS}$ & $\mathrm{g} \cdot \mathrm{m}^{-2}$ & 9.5 & 15.5 \\
Chlorophyll a & $\mathrm{Chl}-\mathrm{a}$ & $\mathrm{mg} \cdot \mathrm{m}^{-2}$ & no data & 4.1 \\
\hline
\end{tabular}


during both campaigns and Chlorophyll $a$ (Chl. $a$ ) in early autumn was around $4 \mathrm{mg} / \mathrm{m}^{2}$. Chl. $a$ was not measured during the early spring campaign, but studies at an adjacent station over an annual cycle between 1991 and 1992 revealed, that $\mathrm{Chl} . a$ in winter and spring was $4 \mathrm{mg} / \mathrm{m}^{2}$ (Landim de Souza, 1993)

\section{Benthic primary production and respiration}

Table 2 presents the estimates for net primary production (light bell-jars over the light period), gross primary production (light and dark bell-jars over the light period), and total community respiration (dark bell-jars extrapolated for the entire day). The differences in the metabolic rate parameters between the two campaigns were mainly quantitative. All rates were about two-fold higher in early autumn than in early spring, but exhibited similar ratios. For example, carbon production in early autumn and early spring ranged between 15.0 and 16.7 $\mathrm{mmolC} / \mathrm{m}^{2} /$ day (i.e 0.48 and $0.52 \mathrm{gO}_{2} / \mathrm{m}^{2} /$ day, $\mathrm{n}=3$ ) and 26.7 and $43.3 \mathrm{mmolC} / \mathrm{m}^{2} /$ day (i.e 0.84 and $1.38 \mathrm{gO}_{2} / \mathrm{m}^{2} /$ day, $\mathrm{n}=4$ ), respectively. Carbon respiration varied between 28.3 and $42.5 \mathrm{mmolC} / \mathrm{m}^{2} /$ day (i.e -0.91 and $-1.37 \mathrm{gO} / \mathrm{m}^{2} /$ day) in early spring and 40.0 and $83.3 \mathrm{mmolC} / \mathrm{m}^{2} /$ day (i.e. -1.27 and $-2.67 \mathrm{gO}_{2} / \mathrm{m}^{2} /$ day) in early autumn. The ratio between net primary production and respiration $(P / R)$ over the light period was 1.1 in early spring and 1.4 in early autumn and between net primary production and total community respiration over 24 hours 0.44 and 0.34 , respectively. Pelagic primary production (PPP) was by a factor of ten lower than benthic primary production (BPP) during both campaigns (Fig.3), with $1.7 \pm 0.7 \mathrm{mmolC} / \mathrm{m}^{2} /$ day $(\mathrm{n}=3)$ in early spring and $4.0 \pm 1.4 \mathrm{mmolC} / \mathrm{m}^{2} /$ day $(\mathrm{n}=3)$ in early autumn.

Table 2. Primary production and respiration rates during the two study periods in the lagoon embayment of São Pedro D'Aldeia/Araruama

\begin{tabular}{|c|c|c|c|}
\hline \multirow[b]{2}{*}{ Compartment } & \multirow[b]{2}{*}{ Community parameters } & \multicolumn{2}{|c|}{ Study period } \\
\hline & & $\begin{array}{l}\text { Early Spring } \\
\mathrm{mmol} \mathrm{C} \cdot \mathrm{m}^{-2} \cdot \mathrm{d}^{-1}\end{array}$ & $\begin{array}{l}\text { Early Autumn } \\
\mathrm{mmol} \mathrm{C} \cdot \mathrm{m}^{-2} \cdot \mathrm{d}^{-1}\end{array}$ \\
\hline \multirow[t]{5}{*}{ Benthic } & Net primary production & $15.4 \pm 0.7$ & $33.8 \pm 8.8$ \\
\hline & Respiration (light period) & $13.8 \pm 3.5$ & $24.1 \pm 6.2$ \\
\hline & Gross primary production & $28.3 \pm 7.2$ & $57.5 \pm 10.3$ \\
\hline & Total community respiration & $35.8 \pm 7.2$ & $65.6 \pm 16.9$ \\
\hline & Total community metabolism & $50.8 \pm 7.8$ & $98.4 \pm 20.6$ \\
\hline Pelagic & Primary production & $1.7 \pm 0.7$ & $4.0 \pm 1.4$ \\
\hline
\end{tabular}

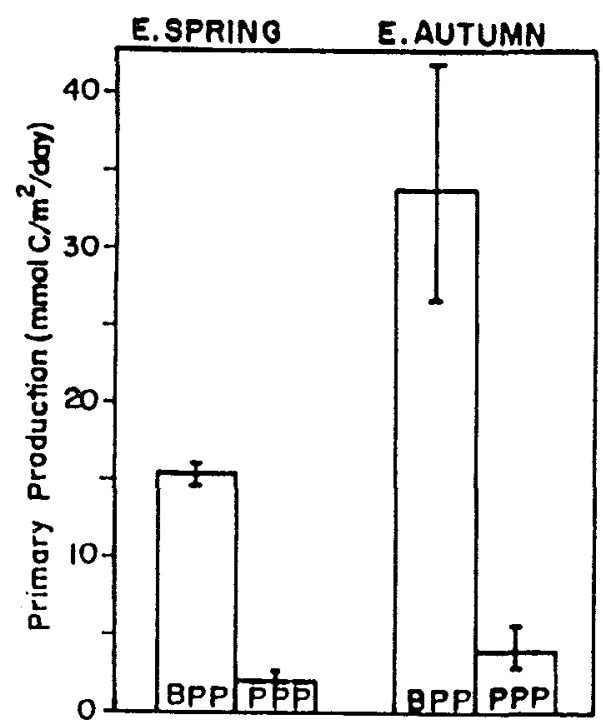

Fig. 3. Pelagic (PPP) and net benthic primary production (BPP) in the early spring and early autumn in São Pedro d'Aldeia, Araruama. 


\section{Benthic nutrient fluxes}

The benthic nutrient fluxes, particularly of DIP, were highly variable in contrast to the oxygen fluxes. This was not surprising, for In Situ benthic chamber and also In Vitro core incubations usually furnish reproducible results for oxygen fluxes but highly variable ones for nutrient fluxes (Nixon et al., 1980; Zeitzschel, 1980; Florek \& Rowe,1983; Klump \& Martens, 1981). The mean benthic ammonia and dissolved inorganic phosphate fluxes (Tab. 3) from the dark bell-jars were $0.65 \pm 0.32 \mathrm{mmolN} / \mathrm{m}^{2} /$ day and $0.02 \pm 0.01$ $\mathrm{mmolP} / \mathrm{m}^{2} /$ day $(\mathrm{n}=3)$ in early spring and $0.58 \pm 0.42$ $\mathrm{mmolN} / \mathrm{m}^{2} /$ day and $0.001 \pm 0.02 \mathrm{mmolP} / \mathrm{m}^{2} /$ day $(\mathrm{n}=4)$ in early autumn, respectively. The ammonia:orthophosphate $(\mathrm{N}: \mathrm{P})$ release ratio was $32: 1$ in early spring and surpassed $580: 1$ in early autumn. The minimum release rate of ammonia was 0.17 and the maximum $1.08 \mathrm{mmol} / \mathrm{m}^{2} /$ day. The range for dissolved inorganic phosphate was -0.03 (uptake) and 0.03 (release) $\mathrm{mmol} / \mathrm{m}^{2} / \mathrm{day}$, for the entire study.

\section{Discussion}

Boundary conditions of the water column and the benthic interface

The main factors affecting benthic oxygen and nutrient fluxes are temperature, light, the supply of oxidants from the overlying water, benthic biomass, composition, and activity, and redox conditions of the sediment surface (Pamatmat, 1971; Zeitzschel \& Davies, 1978; Zeitzschel,1980). Favourable conditions for the supply of oxidants to the bottom and the maintenance of benthic metabolism were encountered during this study. Temperatures were moderately high, the water column was constantly mixed by the action of land-sea breezes, particularly in the afternoon, and sufficient light attained the bottom. However, the potential supply of organic matter from the overlying water to the bottom was small, as indicated by the low pelagic primary production rates and Chlorophyll $a$ biomass. The molar DIN:DIP ratios of the water column implyed that pelagic primary production was limited by phosphorous. Studies by André et al. (1981), FEEMA (1987), and by Landim de Souza (1993) support these findings. Similar oligotrophic conditions of the watercolumn and phosphorous limitation have been observed in many hypersaline carbonate-rich environments (Javor \& Castenholz, 1984; Atkinson, 1987).

The sediment-water interface below the $1-3 \mathrm{~mm}$ thick algal mats and the top few centimeters of the surface sediments lacked $\mathrm{H}_{2} \mathrm{~S}$-odour and the dissolved oxygen saturation levels of the bottom waters were always above $70 \%$ in the early morning. This is no guarantee that the sediments remained oxic over night, but may suggest, that the estimates of the sediment oxygen consumption rates of this study during the day were not substantially affected by a chemical oxygen demand from the oxidation of sulfide to sulphate. It is a well known fact, that chemical oxygen demand attains considerable importance in hyposaline

Table 3. Benthic nutrient fiuxes measured by In situ bell-jar incubations during the two study periods in the lagoon embayment of São Pedro D'Aldeia/Araruama. The daily fluxes from the light bell-jar incubations refer to the light period only (see text). An RQ $=1$ was adopted for the transformation of $\mathrm{O}_{2}$ to $\mathrm{CO}_{2}$. Negative values correspond to uptake rates and positive values to release rates

\begin{tabular}{lccccc}
\hline Study Period & Incubation mode & \multicolumn{3}{c}{ Benthic fluxes } \\
& & $\begin{array}{c}\mathrm{CO}_{2} \\
\mathrm{mmol} \cdot \mathrm{m}^{-2} \cdot \mathrm{d}^{-1}\end{array}$ & $\begin{array}{c}\mathrm{NH}_{4}{ }^{+}-\mathrm{N} \\
\mathrm{mmol} \cdot \mathrm{m}^{-2} \cdot \mathrm{d}^{-1}\end{array}$ & $\begin{array}{c}\mathrm{PO}_{4}^{-3}-\mathrm{P} \\
\mathrm{mmol}^{-2} \mathrm{~m}^{-2} \cdot \mathrm{d}^{-1}\end{array}$ & $\mathrm{n}$ \\
\hline Early Spring & Light & $-15.4 \pm 0.7$ & erratic & erratic & 3 \\
& Dark & $35.8 \pm 7.2$ & $0.65 \pm 0.32$ & $0.02 \pm 0.01$ & 3 \\
Early Autmn & Light & $-33.8 \pm 8.8$ & $-0.21 \pm 0.34$ & $<-0.001 \pm 0.01$ & 4 \\
& Dark & $65.6 \pm 16.9$ & $0.58 \pm 0.42$ & $<0.001 \pm 0.01$ & 4 \\
& & & & & \\
\hline
\end{tabular}


organic-rich environments with anoxic sediments close to the sediment-water interface and in hypersaline systems with consolidated algal mats (Pamatmat, 1971; Zeitzschel \& Davies, 1978; Bauld, 1981; Joye et al., 1996; Epping \& Jörgensen, In press).

\section{Benthic primary production and respiration}

The measurements of this study are limited in number and temporal frequency, but permit some preliminary conclusions. The results suggest the presence of a seasonal trend in pelagic and benthic primary production and respiration. All metabolic rates were by a factor of two higher in early autumn than in early spring (Table 2, Fig. 3). In support, temperatures, suspended organic matter, pelagic primary production, and the allochthonous input of nutrients from domestic discharge from the township of São Pedro D'Aldeia are higher in summer-autumn than in winter-spring (André $e t$ al., 1981; FEEMA, 1987; Landim de Souza, 1993, Landim deSouza $^{*}$ et al., 1995). Clear seasonal trends have also been observed in most of the hyposaline organic-rich phytoplankton or macroalgal based lagoons of the eastern Rio de Janeiro coastline, including L. Saquarema, L. Guarapina, and L. Piratininga. These are subject to a unimodal pattern in algal biomass and primary production with peak rates dominating in summer and early autumn, when temperatures are also highest (Moreira \& Knoppers,1990; Carmouze et al., 1991; Carneiro et al., 1994). Manifold studies have shown that, benthic metabolism in estuaries and coastal lagoons is linked to temperature changes at a monthly to seasonal scale (Pamatmat, 1971; Nixon et al., 1976; Hargrave, 1978; Zeitzschel \& Davies, 1978; Dye, 1983).

Total primary production of SPA was dominated by benthic primary production and benthic community respiration surpassed benthic primary production. One may thus postulate that SPA-Araruama represents a heterotrophic system. Smith (1988) and Smith \& Atkinson (1994) argue that most coastal lagoons, estuaries and coral reef systems are heterotrophic. Nevertherless, many tropical and sub-tropical coastal lagoons also exhibit a balanced metabolism over an annual cycle, including the coastal lagoons of L. Saquarema and L. Guarapina of the State of Rio de Janeiro (Machado \& Knoppers, 1988; Carmouze et al., 1991). However, these lagoons present a seasonal shift between autotrophic and

(*) Landim de Souza, W. F.; Viana, E. F. C.; Landim de Souza, M. F. \& Knoppers, B. A. 1995. O Impacto Antropogênico á Lagoa de Araruama - RJ. In: CONGRESSO BRASILEIRO DE GEOQUÍMICA, 5. Resumos. Rio de Janeiro, SBGQ, 1995. 1 CD-ROM. heterotrophic metabolism, and it seems, that this is a characteristic feature of hyposaline organic-rich tropical coastal lagoons (Knoppers, 1994). The existence of a similar trend in SPA/Araruama has as yet to be established. Concomitant measurements of pelagic and benthic metabolism over an annual cycle are still lacking.

The results on pelagic primary production by André et al. (1981) and those of this study show, that SPA/ Araruama represents a low productive system in comparison to other tropical marine hypersaline environments, characterized by more consolidated algal mats. Phytoplankton together with benthic algal mat production of hypersaline systems lie within a range of 42 to $250 \mathrm{mmolC} / \mathrm{m}^{2} / \mathrm{d}$, or more, and may even surpass those of many tropical and sub-tropical eutrophic phytoplankton based coastal lagoons (Nixon, 1982; Knoppers, 1994). The relatively low primary production of SPA/Araruama may be linked to three main features: 1) the small areal nutrient load of the lagoon (i.e. input per $\mathrm{m}^{2}$ of the watercolumn) (Landim de Souza,1993; Landim de Souza et al., 1995), 2) the constant mixing of the watercolumn and frequent resuspension of bottom material by wind action (Kjerfve et al., 1996) which imposes stress upon the algae and impedes the consolidation of thicker and more productive algal mats, and 3) primary production is severely limited by phosphorous due to control by calcium carbonate reactions at the sediment-water interface (Atkinson, 1987; Smith, 1988; Smith \& Atkinson, 1994).

\section{Benthic nutrient fluxes}

The sediment release rates of ammonia and phosphate of this study were comparable to those of other euryhaline and hypersaline carbonate-rich environments (Table 4), which were also marked by a preferential release of ammonia over DIP. The mean DIN:DIP release ratios with about 34:1 in early spring and over 580:1 in early autumn, were well above the Redfield ratio $\left(\mathrm{N}: \mathrm{P}_{\mathrm{at}}=16: 1\right)$ of the demand by phytoplankton. Thus, $P$ retention at the sediment-water interface was a likely mechanism controling the degree of $\mathrm{P}$ limitation of pelagic primary production. Removal of reactive phosphorous by, for example, the authigenic formation of calcium phosphate (apatite), the inclusion on organic coatings of carbonate grains, and the direct chemical precipitation of amorphous calcium phosphate, were likely some of the processes responsible for the high DIN:DIP release rates (Atkinson \& Smith, 1983; Lyons et al., 1984; Atkinson, 1987; López \& Morgui, 1992). In general, the surface sediments of $L$. Araruama lack organic-bound phosphorus in comparison to nitrogen (Campos et al., 1979). 
Table 4. Benthic nutrient fluxes in tropical hypersaline and carbonate rich environments

\begin{tabular}{|c|c|c|c|c|}
\hline \multirow{2}{*}{$\begin{array}{l}\text { Carbonate-rich } \\
\text { environments }\end{array}$} & \multirow[t]{2}{*}{ System type } & \multicolumn{2}{|c|}{ Nutrient fluxes } & \multirow[t]{2}{*}{ Reference } \\
\hline & & $\begin{array}{r}\mathrm{NH}_{4}^{+}-\mathrm{N} \\
(\mu \mathrm{mol} . \mathrm{I} \\
\end{array}$ & $\begin{array}{l}\mathrm{PO}_{4}^{-3}-\mathrm{P} \\
\left.2 \cdot \mathrm{d}^{-1}\right) \\
\end{array}$ & \\
\hline $\begin{array}{l}\text { Araruama (SPA) - } \\
\text { SE,Brazil }\end{array}$ & $\begin{array}{l}\text { Hypersaline choked } \\
\text { lagoon }\end{array}$ & 170 to 1080 & -30 to 30 & This study \\
\hline $\begin{array}{l}\text { Harrington Sound - } \\
\text { Bermuda }\end{array}$ & $\begin{array}{l}\text { Euryhaline choked } \\
\text { lagoon }\end{array}$ & 1020 & 51 & Bodungen et al. (1982) \\
\hline Shallow waters - Bermuda & $\begin{array}{l}\text { Euryhaline outer reef } \\
\text { lagoon }\end{array}$ & 115 to 312 & 0.5 to 7 & Hines (1985) \\
\hline $\begin{array}{l}\text { Tikehau - } \quad \text { French } \\
\text { Polynesia }\end{array}$ & $\begin{array}{l}\text { Euryhaline Atoll } \\
\text { lagoon }\end{array}$ & 4 to 307 & 1 to 12 & $\begin{array}{l}\text { Charpy-Rouband, et al. } \\
\text { (1996) }\end{array}$ \\
\hline South Sulawesi - Indonesia & $\begin{array}{l}\text { Euryhaline coastal } \\
\text { reef }\end{array}$ & 104 to 306 & 38 to 112 & $\begin{array}{l}\text { Erftemeijer and Middelburg } \\
\text { (1993) }\end{array}$ \\
\hline $\begin{array}{l}\text { Bowling Green Bay - NE } \\
\text { Australia }\end{array}$ & $\begin{array}{l}\text { Eurihaline coastal } \\
\text { reef }\end{array}$ & -150 to 890 & -20 to 28 & $\begin{array}{l}\text { Ullmann and Sandstroem } \\
\text { (1987) }\end{array}$ \\
\hline Maribago - Phillipines & $\begin{array}{l}\text { Euryhaline coastal } \\
\text { reef }\end{array}$ & erratic & 60 to 240 & Balzer et al. (1985) \\
\hline $\begin{array}{l}\text { Kanehoe Bay - Hawaii, } \\
\text { USA }\end{array}$ & $\begin{array}{l}\text { Euryhaline coastal } \\
\text { lagoon }\end{array}$ & 1180 & 12 & Smith et al. (1981) \\
\hline
\end{tabular}

This study also suggests, that the sediment-water interface represents a main source of ammonia to the watercolumn, which, together with nitrate, is abundant throughout the year (Landim de Souza, 1993; Landim de Souza et al., 1995). Ammonia originating from the input of domestic effluents seems to be of secondary importance, because of marked dilution of the nutrient load by the lagoon's large water volume (Landim de Souza et al., op. cit.). However, the importance of the input of ammonia and also nitrate via ground water seepage is as yet unknown.

\section{Benthic nutrient fluxes and the demand by pelagic primary production}

In spite of the low number of measurements, an attempt is made to estimate how much of the benthic nutrient supply potentially sustained pelagic primary production in this study. Under the assumption that the phytoplankton of SPA resembled the Redfield Ratio in composition, the nutrient demand by pelagic primary production was 0.26 $\mathrm{mmolN} / \mathrm{m}^{2} /$ day and $0.016 \mathrm{mmolP} / \mathrm{m}^{2} /$ day in early spring and $0.60 \mathrm{mmolN} / \mathrm{m}^{2} /$ day and $0.04 \mathrm{mmolP} / \mathrm{m}^{2} /$ day in early autumn. The daily benthic ammonia release rates from the dark incubations sufficed to cover $260 \%$ in early spring and $95 \%$ in early autumn of the demand by phytoplankton primary production, and DIP around $100 \%$ and less than $5 \%$, respectively. These assertions are of course overestimates, because nutrients were also taken up during the light period by benthic primary production (Table 3; early autumn values). Unfortunately, the nutrient uptake rates obtained from the light incubations were erratic during the early spring period (Table 3 ). By subtracting the uptake rates during the light period from the daily release rates of the dark incubations, ammonia would have still covered well over $100 \%$ of the phytoplankton demand in early autumn.

In shallow organic-rich coastal lagoons, the benthic supply of both ammonia and orthophosphate generally sustains 15 to $30 \%$ of the annual demand by pelagic primary production (Knoppers, 1994), and at some stages of an annual cycle it may even attain $100 \%$ (Zeitzschel, 1980). Similar general trends for hypersaline carbonate-rich environments have as yet to be established, due to the paucity of concomitant estimates on benthic nutrient fluxes and pelagic primary production in these systems. It seems, that benthic nutrient release rates, particularly DIP, of tropical hypersaline and carbonate-rich environments (Table 4) are lower than those of organic-rich systems (Nixon, 1982; Nixon \& Pilson, 1983; Knoppers, 1994). In order to better understand the mechanisms which control the trophic state and eutrophication of Araruama lagoon, higher frequency measurements of benthic metabolism, nutrient fluxes, and, in particular, the phosphorous dynamics at the sediment-water interface have to be performed. 


\section{Acknowledgements}

We are indebted to Dr. Ricardo Coutinho for his management efforts of the PROLAGOS project and for assistance in the field. This work was financed by Instituto Acqua, Petrobrás, and CNPq (Brazilian Council for the Development of Science and Tecnology). Marcelo, Weber and Elisa were supported with student scholarships from CNPq.

\section{References}

André, D. L.; Oliveira, M. C.; Okuda, T.; Horta, A. M. T. C.; Soldan, A. L.; Moreira,I. M. N. S.; Rollemberg, M. C. E. \& Heinzen, V. E. F. 1981. Estudo preliminar sobre as condiçôes hidroquímicas da lagóa de Araruama - Rio de Janeiro. Inst. Pesq. Mar., 139:1-35.

Atkinson, M. \& Smith, S. V. 1983. C:N:P ratios of benthic marine plants. Limnol. Oceanogr., 28(3):568-574.

Atkinson, M. J. 1987. Low phosphorus sediments in a hypersaline marine bay. Estuar. coast. Shelf Sci,, 24:335-347.

Baeta Neves, M. H. C. 1983. Flora ficológica da lagoa hipersalina da Araruama (Estado do Rio de Janeiro Brasil) 2. Cyanophyceae. Inst. Pesq. Mar., 149:1-18.

Balzer, W.; Bodungen, B. von \& Pollehne, F. 1985. Benthic degradation of organic matter and regeneration of nutrients in shallow water sediments off Mactan, Philippines. Philipp. Scient., 22:30-41.

Barbiéri, E. B. 1975. Ritmo climático e extraçao do sal cm Cabo Frio. R. bras. Geogr., 37(4):23-109.

Bauld, J. 1981. Geobiological role of cyanobacterial mats in sedimentary environments: production and preservation of organic matter. J. Aust. Geol. Geophy., 6:307-317.

Bauld, J. 1984. Microbial mats in marginal environments: Shark bay, western Australia and Spencer gulf, south Australia. In: Cohen, Y.; Castenholz, R. W. and Halvorson, H. O., eds Microbial Mats: Stromatolites. MBL Lectures in Biology, 3:39-58.
Bodungen, B. von; Jickells, T. D.; Smith, S. R.; Ward, J. D. \& Hillier, G. B. 1982. The Bermuda marine environment III. Bermuda Biological Station Special Publication, 18: 1-123.

Campos, R. C.; Queiroz, M. I.; Lacerda, R. E. D. \& Okuda, T. 1979. Conteúdo de fósforo total, carbono e nitrogênio na forma orgânica, nos sedimentos da lagoa de Araruama. Inst. Pesq. Mar., 142:1-7.

Carmouze, J. P.; Knoppers, B. \& Vasconcellos, P. 1991. The eutrophication of the lagoon of Saquarema. Biogeochem., 14: 129-148.

Carneiro, M. E. R.; Azevedo, A.; Ramalho, N. M. \& Knoppers, B. 1994. A biomassa de Chara Homemannii em relação ao comportamento físico-químico da lagoa de Piratininga (RJ). An. Acad. bras. Ci., 66:213-222.

Charpy-Rouband, C.; Charpy, L. \& Sarazin, G. 1996. Diffusional nutrient fluxes at the sediment-water interface and organic matter remineralization in an atoll lagoon (Tikehan, Tnamotu Archipelago, French Polynesia). Mar. Ecol.-Prog. Ser., 132:181- 190.

Cohen, Y.; Castenholz, R. W. \& Halvorson, H. O. 1984. eds Microbial Mats: Stromatolites. MBL Lectures in Biology, vol. 3. New York, Alan R. Liss 489p.

Dye, A. H. 1983. Oxygen comsumption by sediments in a southern African mangrove swamp. Estuar. coast. Shelf Sci., 17(4):473-478.

Epping, E. H. G. \& Jorgensen, B. B. In Press. Light enhaced oxygen respiration in benthic phototrophic communities. Mar. Ecol. Prog. Ser.

Erftemcijer, P. L. A. \& Middclburg, J. J. 1993. Sedimentnutrient interactions in tropical seagrass beds: a comparison between a terrigenous and a carbonate sedimentary environment in South Sulawesi (Indonesia). Mar. Ecol. Prog. Ser., 102:187-198.

FEEMA Fundação Estadual de Engenharia do Meio Ambicnte. 1987. Qualidade das águas do estado do Rio de Janciro, FEEMA. v. 2. 86p. + anexos.

Florck, R. O. \& Rowe, G. T. 1983. Oxygen comsumption and dissolved inorganic nutrient production in marine coastal and shelf sediments of the middle Atlantic Bight. Int. Revue ges. Hydrobiol., 68:73-112. 
Grasshoff, K; Ehrardt, M. \& Kremling, K. 1983. Methods of seawater analysis. Weihein, Verlag Chemie. 419p.

Hargrave, B. T. 1969. Similarity of oxygen uptake by benthic communities. Limnol. Oceanogr., 14(5):801-805.

Hargrave, B. T. 1978. Seasonal changes in oxygen uptake by settled particulate matter and sediments in a marine bay. J. Fish. Res. Bd Can., 35(12):1621-1628.

Hines, M. E. 1985. Microbial biogeochemistry in shallow water sediments of Bermuda. In: Proc. 5 th. Int. Coral Reef Congr. 3: 427- 432.

Javor, B. J. \& Castenholz, R. W. 1984. Productivity studies of microbial mats. Laguna Guerrero Negro, Mexico. In: Cohen, Y.; Castenholz, R. W. \& Halvorson, H. O., eds. Microbial Mats: Stromatolites. MBL Lectures in Biology, 3:149-170.

Javor, B. J. 1989. Hypersaline environments microbiology and biogeochemistry. Berlin, Springer Verlag. 328p.

Jörgensen, B. B.; Revsbech, N. P. \& Cohen, Y. 1983. Photosynthesis and structure of benthic microbial mats: Microelectrode and SEM studies of four cyanobacterial communities. Limnol. Oceanogr., 28(6):1075-1093.

Joye, S. B.; Mazzotta, M. L. \& Hollibaugh, J. J. 1996. Community metabolism of microbial mats: the occurrence of biologically- mediated iron and manganese reduction. Estuar. coast. Shelf Sci. 43(6):747-766.

Kjerfve, B.; Schettini, C. A. F.; Knoppers, B.; Lessa, G. \& Ferreira, H. O. 1996. Hydology and salt balance in the world's largest hypersaline coastal lagoon: lagoa de Araruama, Brazil. Estuar. coast. Shelf Sci. 42(6):701-727.

Klump, J. V. \& Martens, C. S. 1981. Biogeochemical cycling in an organic rich coastal marine basin. $\Pi$. Nutrient sediment-water exchange process. Geochim. cosmochim. Acta., 45:101-121.

Klump, J. V. \& Martens, C. S. 1987. Biogeochemical cycling in an organic rich coastal marine basin: V. Sedimentary nitrogen and phosphorus budgets based upon kinetic models, mass balances, and the stoichiometry of nutrient regeneration. Geochim. cosmochim. Acta., 51:1161-1173.
Knoppers, B. 1994. Aquatic primary production in coastal lagoons. In: Kjerfve, B., ed. Coastal lagoon process. Amsterdam, Elsevier. p. 243-286.

Krumbein, W. E. 1983. Microbial geochemistry. Oxford, Blackwell Scientific Publication. 330p.

Landim de Souza, M. F. 1993. Distribuição espacial, sazonal e fontes fluviais de nutrientes na lagoa de Araruama - RJ. Dissertação de mestrado. Universidade Federal Fluminense, Departamento de Geoquímica. 167p.

Lenz, J. 1971. Zur methode der Sestonbestimmungs. Kieler Meeresforch., 27:180-193.

López, P. \& Morguí, J.A. 1992. Phosphate and calcium carbonate saturation in a stratified coastal lagoon. Hydrobiol., 228:55-63.

Lyons, W. B.; Hines, M. E. \& Gaudette, H. E. 1984. In: Cohen, Y.; Castenholz, R. W. and Halvorson, H. O., eds. Microbial Mats: Stromatolites. MBL Lectures in Biology, 3:411-423.

Machado, E. C. \& Knoppers, B. 1988. Sediment consumption in an organic rich sub-tropical lagoon, Brazil. Sci. Tot. Environ., 75:341-349.

Moreira, P. F. \& Knoppers, B. A. 1990. Ciclo anual de produção primária e nutrientes na lagoa de Guarapina, RJ. Acta Limnol. Bras., 3:275-290.

Muehe, D. 1994. Lagoa de Araruama: geomorfologia e sedimentação. Cad. Geoc., 10:53-62.

Nixon, S. W.; Oviatt, C. A. \& Hale, S. S. 1976. Nitrogen regeneration and the metabolism of coastal marine bottom communities. In: Anderson, J. M. \& Macfaydan, A. eds . The role of terrestrial and aquatic organisms in decomposition processes. Oxford, Blackwell Scientific Publications. p.269-283.

Nixon, S. W.; Kelly, J. R.; Furnas, B. N.; Oviatt, C. A. \& Hale, S. S. 1980. Phosphorus regeneration and the metabolism of coastal marine bottom communities. In: Tenore, K. R. \& Coull, B. C. , eds. Marine benthic dynamics. Columbia, Univ. of South Carolina Press. p.219-241. 
Nixon, S. W. 1982. Nutrients, primary production and fisheries yields in coastal lagoons. Oceanol. Acta, 5:357-371.

Nixon, S. W. \& Pilson, M. 1983. Nitrogen in estuarine and coastal marine ecosystems. In: Carpenter, E. J. \& Capone, D. G., eds. Nitrogen in the marine environment. New York, Academic Press. p.565-648.

Pamatmat, M. M. 1971. Oxygen consumption by the sea bed. IV. Shipboard and laboratory experiments. Limnol. Oceanogr., 16(3):536-549.

Smith, S. V.; Kimmerer, W. J.; Laws, E. A.; Brock, R. E. \& Walsh, T. W. 1981 Kaneohe Bay sewage diversion experiment: perspectives on ecosystem responses to nutritional perturbation. Pacif. Sci., 35(4):279-402.

Smith, S. V. 1988. Mass balance in coral reef-dominated areas. In: Jansson, B. O., ed. Coastal-offshore ecosystem interactions. Lecture Notes on Coastal and Estuarine Studies, 22:09-226.

Smith, S. V. \& Atkinson, M. J. 1994. Mass balance analysis of carbon, nitrogen, and phosphorus fluxes in coastal water bodies, including lagoons. In: Kjerfve, B., ed. Coastal lagoon process. Amsterdam, Elsevier. p. 133-155.

Steemann-Nielsen, F. 1954. On organic production in the ocean. J. Cons. int. Explor. Mer., 19(3):309:328.
Strickland, J. D. H. \& Parsons, T. R. 1972. $2^{\text {nd }}$ ed. A practical handbook of seawater analysis. Bull. Fish. Res. Bd Can., 167:311p.

Ullman, W. J. \& Sandstroem, M. W. 1987. Dissolved nutrient fluxes from nearshore sediments of Bowling Green bay, central Great Barrier Reef lagoon (Australia). Estuar. coast. Shelf Sci., 24:289-303.

Williams, P. J. LeB. \& Robertson, J. E. 1991. Overall planktonic oxygen and carbon dioxide metabolisms: the problem of reconciling observations and calculations of photosynthetic quotients. J. Plankt. Res., 13:153-169.

Zeitzschel, B. \& Davies, J. M. 1978. Benthic growth chambers. Rapp. P.-v. Réun. Cons. perm. int. Explor. Mer., 173:31-42.

Zeitzschel, B. 1980. Sediment-water interactions in nutrient dynamics. In: Tenore, K. R. and Coull, B. C., eds. Marine benthic dynamics. Columbia, Univ. of South Carolina Press. p.195-218.

(Manuscript received 06 October 1996; revised 21 February 1997; accepted 28 April 1997) 